\title{
Outstanding Rhetorical Devices and Textuality in Obama’s Speech in Ghana, Africa
}

\author{
Concepción Hernández-Guerra \\ University of Las Palmas de Gran Canaria, Gran Canaria, Spain \\ Email: chernandez@dfm.ulpgc.es
}

Received July $17^{\text {th }}$, 2012; revised August 28 ${ }^{\text {th }}$, 2012; accepted September $4^{\text {th }}$, 2012

\begin{abstract}
Latest trends in political discursive analysis have shown the importance of the study done from the textual and contextual perspective alike. An oral speech has the property of having been prepared in advance but expressed with some improvisation so characteristics from written and oral texts must be taken into consideration. As a consequence, the structure of the discourse and the personal contribution of the author are seemingly relevant. The oral speech analyzed here was expressed in Ghana, Africa by President Barack Obama in 2009. Given the circumstances of Obama's African origin and of visiting the country as the President of the United States, the elements that reveal the personal attitude comprise an extra interest. The aim of this paper is to analyze the speech from a discursive viewpoint in order to describe the textual and intertextual functions.
\end{abstract}

Keywords: Political; Discourse; Textual; Intertextual; Analysis

\section{Introduction}

Some of the most important points of attractiveness in the recent history of linguistics as a science are the different perspectives from which text analysis can be carried out. That is why discourse analysis is becoming a discipline that brings together linguistics researchers from different areas. According to the text to be analyzed, one will be more suitable than others. But the common ground is that analysts start from the same proposition: a text.

Text linguistics is always descriptive and, from this perspective, we analyze what words are used, how a message is said and how discourse is built upon (Coulthard, 1994). Through linguistics analysis we guess the possible textualization of the writer's message but there is another vision to interpret texts, i.e., what is the purpose of such a text and how the combination of the different utterances fulfills that purpose.

The oral speech genre covers this interpersonal metafunction of language remarkably as the channel used for communication is face-to-face and the perlocutionary effect must be immediate. That is, the speaker wants a prompt response to his speech. To do this, the illocutionary force must be strongly biased. This idea may be seen in Table $\mathbf{1}$.

This subcategory of political discourse has had different denominations: prepared speech, non-spontaneous oration, or spoken monologue, and comprises three characteristics: it has been delivered to a large audience, it has been prepared beforehand, and the audience has to process that talk as being delivered.

\section{Method}

I shall base my research on the text analysis offered by $\mathrm{T}$. Locke (2004), updated with P. Simpson's contribution (2010), as this frame bases the study not only on the linguistics elements but also the text structure and the intertextuality (Simpson, 2010: p. 45). From the diagram offered we have selected the elements found in our text. They are expressed in Table 2.

With the vocabulary analysis we shall go over the condition of the text: whether it is optimistic or pessimistic, whether words with the same meaning are used and if they are frequent, the role of metaphors; i.e., if they are used with a hopeful purpose or describing the critical situation that a country like Ghana is in. To put in a nutshell, concluding the implicit purpose of the speech with a first estimation. Vocabulary will also be seen in the chapter dedicated to cohesion.

Grammar analysis will be based on verbs, which voice they express, and their modality or transitivity. On the other hand, the use of the pronouns, i.e., whether the use of "we" implies "you and I" or "Americans and I" and others; the different uses of "you", whether he makes reference to the citizens of Ghana or, on the contrary, to the government. With this analysis we shall guess in the message the compromise the speaker expects from the hearers.

With the cohesive section in Table 2, we shall overview the style in the speech but the use of parallelisms, argumentation and connectives are also included. And, finally, text structure, including the role of elements like presupposition and implicature are included. With them, we shall come across the level of knowledge Obama has of the country and their problems. We shall also ascertain the interactional control of the text as a whole.

Following this proposal, we are fulfilling the two-fold purpose in this paper; that is, carrying out an analysis of the text from a discursive point of view and concluding the personal implication of the author.

Table 1.

Relationship between speaker and hearer in an oral speech.

\begin{tabular}{ccc}
\hline Speaker & Channel & Hearer \\
\hline $\begin{array}{c}\text { Clearly stated } \\
\text { Illocutionary force }\end{array}$ & Face-to-face & Immediate \\
& Media & perlocutionary act \\
\hline
\end{tabular}


Table 2.

Locke's and Simpson's updated text analysis model.

\begin{tabular}{llll}
\hline Vocab. & Grammar & Cohesion & Text structure \\
Formal/inf & Modality & Connectives & Presupposition \\
Metaphors & Transitivity & Argumentation & Implicature \\
Wording & Types of verbs & parallelism & Intertextuality \\
Express. values & Pronouns & & \\
& Voice & & \\
\hline
\end{tabular}

\section{Corpus}

The model will be applied to a speech stated by President Barack Obama in the town of Accra in Ghana, Africa, in 2009, the same year that he was elected President of the United States. This speech covers the following parts: firstly, President Obama opens the dissertation explaining the reason of his visit to Ghana. The tone is positive as he is hopeful with the future of the country. He remarks the mutual responsibility that both countries have in the progress of Africans. This encouraging presentation is reinforced with the personal reference to his own family when he lived in Africa. The second part of the speech covers the nuts and bolts as faced nowadays: the unfulfilled promises and the responsibility that the country itself has to solve their own problems. It also condemns corruption but gives hope to youngsters. After that, he expresses the four problems he will deal with in the speech: democracy, opportunity, health and the resolution of conflicts. In all of them, he faces the current problems but exemplified in other African countries. To the second and third predicaments he offers economic solutions and in the fourth, a promise. He ends with a hopeful and encouraging message and a Martin Luther King quotation when he visited this country.

\section{State-of-the-Art}

Politics as discourse is a constantly redefined area. David Bell expressed that "we are all political beings in our everyday life" (Bell, 1975: p. 10) and adds that if politics is communication, we must study who talks to whom and what they say (1975: p. 93). Schäffner (1997) also admitted that political language, political discourse and political text themselves are vague terms (1997: p. 1) and that political speeches are not a homogeneous genre. Instead, there is a range of subtypes determined by the particular communicative situation. They have in common that politicians try to get some aims in their development and our aim is to explore the ways of language, how they simplify and assist to create this function (Lakoff, 1990: p. 4). I shall explain within the next lines every area of study in this paper:

\section{Vocabulary}

We start this analysis from the micro-level and ask what specific structures (e.g. word choice) serve to fulfill which strategies (Schäffner, 1975). Different models have been followed for the study of the nouns. Halliday and Hasan (1985) divide them into reiteration (that includes the same word, synonyms, superordinates and general words) and collocation (opposite meaning and typically associated) but it was reclassified in 1994 into repetition, synonymy and collocation. Källgren (see
Heydrich, 1989: p. 37) offered the next division: repetition, synonymy, hyponymy, comparison and inference.

On the other hand, the use of metaphors in texts and in current life has been a source of interesting literature during the last decades (see, for instance, Van Remortel, 1986; Lakoff \& Johnson, 1980; Goos, 1995; Cameron, 1999; Leezenberg, 2001; Simon-Vand, 2001; Ritchie, 2006; Vega Moreno, 2007; Parrill, 2010). Metaphor used in the discourse genre of political rhetoric has been talked about since Aristotle (Cameron, 1999: p. 9) and, recently, it is accepted the link between metaphor and thought as this is structured metaphorically and what flows is the surface of those complex mechanisms that form the thought. Saying this, it seems that we have forgotten in a way the metaphor as a matter of language. So, as Cameron states (1999: p. 107) "a metaphor must include at least one lexical item (the Vehicle term) referring to an idea, entity, action, etc. (the Topic), and that the Vehicle term belongs to a very different, or incongruous, domain from the Topic."

Lastly, by wording I mean the various ways (too many "word" words listed) a meaning can be worded (Locke, 2004; Fairclough, 1992). The use of different words or expressions to refer to the same concept reflects the importance and intensity the speaker wants to denote in order to reinforce the idea.

\section{Grammar}

The chapter of pronouns leads us to the concept of "footing", widely discussed by Goffman (1981) and Levinson (1988), who used it to establish a framework for the analysis of different and complicated roles speakers and hearers have within situations of verbal communication (Schäffner, 1997: 9). Ensink (in Schäffner, 1997: 24) supports the analysis of footing as relevant in political communication since.

The discourse analytic phenomena related to footing put a sharp focus on what is represented in political communication, both as it relates to the speaker and to the audience. Part of political communication takes place on the explicit level of the message. An important part occurs on the level of what the speaker's footing presupposes as to representativeness.

As Levinson points out, the study of footing phenomena is (from a linguistic viewpoint) relevant because these phenomena are at the heart of the concept of deixis and shifters. Shifters provide cues about the interactional significance of an utterance (Wortham, 1996: p. 331) and have been a matter of study since Jakobson (1971) and Jespersen (1965) as deictics, in the case of personal pronouns.

\section{Cohesion}

A lot of literature has been written about cohesion and cohesiveness, taking different perspectives into consideration. Halliday and Hasan (1976) have two terms for types of lexical cohesion, reiteration and collocation. Others prefer to use repetition instead of reiteration, being this one the repetition of a lexical item, either identically or in a modified form whereas the collocation makes reference to the "keep each other company” (Tankskanen: 2006: p. 12). She (2006: p. 7) offers the following definition: "Cohesion refers to the grammatical and lexical elements on the surface of a text which can form connections between parts of the text. Coherence, on the other hand, 
resides not in the text, but is rather the outcome of a dialogue between the text and its listener or reader."

It has been widely discussed whether cohesion markers create cohesion (de Beaugrande \& Dressler, 1981: p. 3; Brown \& Yule, 1983: p. 195; Ellis, 1992: p. 148; Enkvist, 1978; Hellman, 1995; Lundquist, 1985; Sanford \& Moxey, 1995) summarizing in that "they are signals to the reader to look for a more or less well-defined relation between two discourse segments" (Rickheit, 1995: p. 193) but for the purpose of this paper they will help to analyze the level of textuality.

I shall try to develop a model capable of apprehending all cohesively meaningful relations in this text. There have been several attempts in this area (Halliday \& Hasan, 1976; Heydrich, 1989; Kehler, 2002; Tanskanen, 2006). Traditionally, coherence can be analyzed from a grammatical or lexical perspective. Grammatical analysis is easier to develop as the frame is clearly established, whereas lexical analysis has had many approaches. We shall follow Tanskanen's proposal as it is comprehensive and fits better with the characteristics of the text. The analysis of the categories of lexical cohesion is shown in Section 1 in Table 3 and makes reference to words repeated identically or with a slight change in number or tense. Complex repetition words 2) are words with different grammatical functions or words that share a lexical morpheme; substitution 3) makes reference to pronouns, and items like one, do and so. Some researchers include ellipsis in this category but will be left outside the present analysis; equivalence 4) alludes to synonymy, and generalization 5) refers to a superordinate or hyponymic relation; specification 6) is the opposite of generalization, that is meronymy: the relation between an item and a more specific item; co-specification 7) defines the relation between two items which have a common general item; and contrast 8) or antonymy refers to the relation between an item and another item which has an opposite meaning.

Collocation relations have three sub-categories called ordered set 9) the first section in Table 3. It makes reference to the members of ordered sets of lexical items (colours, days of the week, and so on). Activity-related collocation 10) is the way in which "actions, people, places, things and qualities, configure as activities" (Martin, 1992). Finally, elaborative collocation 11) is the case in which items can somehow elaborate or expand on the same topic. In this chapter, too, we shall include argumentation, which represents the reasons to support an idea, and parallelism.

Table 3.

Tanskanens' categories of lexical cohesion.

\begin{tabular}{ll}
\hline \multicolumn{1}{c}{ REITERATION } & \multicolumn{1}{c}{ COLLOCATION } \\
\hline 1) Simple repetition & 9) Ordered set \\
2) Complex repetition & 10) Activity-related collocation \\
3) Substitution & 11) Elaborative collocation \\
4) Equivalence & \\
5) Generalization & \\
6) Specification & \\
7) Co-specification & \\
8) Contrast
\end{tabular}

\section{Text Structure}

This chapter deals with large scale organizational properties, i.e., the interactional control of the content. This is important, although the speaker has the control over the message. As said above, political speeches are in the middle way between oral and written texts. We shall take into consideration Collins' (2010: p. 203) characteristics of political discourse in written and spoken texts.

The relation between textual units can, in many cases, be viewed as a relation between a nucleus and one or more satellite(s) (Korzen \& Heslund, 1998: p. 10). The nucleus is the axis, the textually central part and the satellites are the circumstantial expansions such as explanations and causes. This relationship can be hierarchical (with a principal nucleus and some ancillary satellites), or coordinated (in which no part is seen as ancillary to others).

Another resource is the poetic features that contribute to cohesion. Poetical devices, i.e. alliteration, repetition and rhyme are used to draw attention to linked meanings, and make the associations easier to remember (Collins, 2010: p. 170). We shall also include intertextuality based on parallelism and external references.

\section{Results}

When we cope with a text we have some expectations about it. Reading a letter is not the same as reading an advertisement. All of us own previous information about what formal characteristics the text will have. This is what has been called the frame of discourse. Thanks to this frame, we can predict the use of specific features related to the category of text. "They allow us to make predictions and generalizations. [...] Within the frame, things are unmarked: normal, predictable, orderly, neutral and simple.” (Lakoff, 2000: pp. 47-48).

The text we present here is a speech expressed to a heterogeneous audience with political bias. In general terms, we expect a discourse with a clear message expressed with examples, some rhetoric and remarkable sentences. It is not surprising that informal language abounds over formal vocabulary. The word simple, for instance, is used three times to accompany nouns like reason, truth and promise. The informality is also seen when he explains African history through his own family's eyes. The evolution suffered from his grandfather's way of living to his father's. To put in a nutshell, Obama defines colonialism from his personal experience.

The use of adjectives throughout the text is also significant. These terms are positive and encouraging. Words like considerable, peaceful, improved, emerging, impressive, promising, strong, sustainable, countless, better, broader, great, multiple, wealthy, enormous or innovative are some of the examples when describing Africa's perspectives. On the contrary, when talking about the drawbacks of the continent, the lack of adjectives is the rule, with the exception of brutal, badly and tragic.

After several readings of the text, I have divided the vocabulary into five big groups: positive, negative, politics, neutral and words of countries or cities. The text is composed of around 3000 words and the vocabulary we have extracted represents about 900 words.

Positive words have a confident and constructive intention. They represent the third part of all of them. Considering the most repeated words we have, partners with their derivatives 
(partnership...) that is said nine times, future, that is also repeated nine times, progress and opportunity. Positive words have a remarkable presence over the rest of the groups and can be grouped following the pattern in Table 4.

Ghana is described as an example of good governance and of democratic parliament and doesn't hesitate in praising the country in every topic. The adjectives, as said before, are mostly used with positive nouns.

Negative words sum up half of what are the positive ones and can be grouped into global or general problems, problems in Africa and problems brought out of Africa. The most repeated words are disease and conflict.

In Table 5, critical words towards corrupted African countries are severe and plentiful, but Obama also states that this is not the case of Ghana. He enumerates the unacceptable things in a democratic country who wants to establish some kind of relationship with America.

Added to this, words referring to politics are not many and make reference to the different ways to name the government (parliament, administration, institutions). Neutral words are defined like that because they do not have any implication. They are less represented in number than the positive but are more numerous than the negative. The most common are people (28 times) and children (5 times).

It is also remarkable the large number of African countries he names throughout his exposition. There are more than twenty countries or towns of Africa mentioned. The word Africa is said 37 times, Ghana and its derivatives 17 and the country of America, 10 times.

Metaphors are worth being mentioned in a separate paragraph for their frequency and implicit meaning. Concepts like Africa, partnership, boundaries, or expressions like birth of a nation or firmer footing are abstract concepts prone to be used in a metaphorical way. Reddy (Ritchie, 2006: p. 6) further argued that "the specific metaphors we use shape the way we think about and behave toward these entities." For political discourse this is a good resource because it provides, on one hand, a way of softening the delicate matters and, on the other, some poetry for the hopeful ones.

Thus, around forty examples have been extracted that can be arranged into three blocks. The first block consists of promising and hopeful metaphors. In this group, we find lots of images related to the links and ties between Africa, America, and the rest of the world. We could also include other literary images as in the expressions unlock Africa's potential, people lifted out of poverty, freedom is your inheritance or Africa's boundless natural gifts. Moreover, expressions composed with birth, give birth, and birth of a nation are plentiful.

The second group consists of warlike words. In this way, we find expressions like bred conflict, fight neglected tropical disease, Africa is not the crude caricature of a continent in war, these conflicts are a millstone around Africa's neck. These are not so diverse but quite strong in meaning. There is a sentence that is worth mentioning apart: I have the blood of Africa within $m e$. The use of the word blood may have two meanings: firstly, denoting that he has African blood as his father was African but, secondly, blood as a term related to wounds, suffering and death.

The third group is formed by the terms related to jury. He often states that what he is saying is not his opinion but the truth: History offers a clear verdict, It is the death sentence of a society to force children to kill in wars, We witness the triumph of justice. They are less common.
Table 4.

Sample of positive words in the text.

\begin{tabular}{lll}
\hline $\begin{array}{l}\text { Words referring to } \\
\begin{array}{l}\text { Ghana or Africa' } \\
\text { present }\end{array}\end{array}$ & $\begin{array}{l}\text { Words referring to } \\
\text { Ghana's future }\end{array}$ & America's compromise \\
\hline $\begin{array}{l}\text { Democracy, strength, } \\
\text { human rights, energy, }\end{array}$ & $\begin{array}{l}\text { Promise, triumphs, } \\
\text { improved governance, } \\
\text { significant, promis- } \\
\text { ing, important, talent, } \\
\text { energy, good gov- } \\
\text { ernance }\end{array}$ & $\begin{array}{l}\text { Support, aid, more } \\
\text { resources, funds, food }\end{array}$ \\
\hline
\end{tabular}

Table 5.

Sample of negative words in the text.

\begin{tabular}{lll}
\hline General problems & Problems in Africa & $\begin{array}{l}\text { Problems brought out } \\
\text { of Africa }\end{array}$ \\
\hline $\begin{array}{l}\text { Warming planet, crisis, } \\
\text { mosquito bite, malaria, } \\
\text { global security } \\
\text { challenge, drama, poor } \\
\begin{array}{l}\text { and rural areas, } \\
\text { greenhouse gas, } \\
\text { destruction }\end{array}\end{array}$ & $\begin{array}{l}\text { corruption, drug } \\
\text { traffickers, brutality, } \\
\text { bribery, tyranny, }\end{array}$ & $\begin{array}{l}\text { Patronage, colonial- } \\
\text { ism, tragic past, } \\
\text { unnatural borders, } \\
\text { unfair terms of trade, }\end{array}$ \\
\hline
\end{tabular}

Within the wording (vocabulary in Table 2), we find the insistence of the President in the connection between both continents and the idea of partnership, working together. In this way, we can read expressions like ties, boundaries, connections, partners with America, mutual responsibility (twice), and foundation of our partnership.

With reference to the expressive values, the encouraging utterances throughout the speech are sensible. Sentences like your prosperity is America's, your health and security is the world's, or our strength is the democracy reinforces the idea of a country that must not feel alone, that things are being done right. The problems that Africa faces are reflected in other country's instances.

Indexical shifters like $I$ and we are always interesting to analyze as they can be ambiguous and ingenious. In the text, the personal pronoun "I" appears 24 times to denote a personal interest in the country (I see Africa, I see this knowing full well, I believe, I have no doubt) but, also, to express personal implication to problems (I have pledged, I have directed, I can promise). The pronoun "we", on the other hand, appears 47 times with different implications: firstly, to denote "you and I". This happens at the beginning of the text and in the last paragraph. The most frequent meaning in use is "you and the world". With the verb "see" it has been used 8 times and in a way denotes the idea that all of us are equals. Other examples are: We all have many identities, we are all God's children to proclaim tolerance. Another use of the first person plural pronoun is to describe American Administration. No less than 12 times Obama has expressed this with examples like: We spend, we have a responsibility, we will carry forward, we will invest or we will fight. It is also used to denote American Administration and Ghanaian in examples like we are partners (used twice), what we will do, we must support or we must stop. Another meaning is "America and the West" or developed countries. I have found three examples in expressions like: We use energy, we can also work with Africans and we know that more progress can be made. Lastly, there is one more interesting interpretation, that of "African-Americans": at the end of the speech and in two occasions he explains the achievements of 
the community with expressions like we have done and we have drawn as examples of how this group has overcome the difficulties.

The examples of the second personal pronoun ("you”) as object is not employed so often as the previous case (only 15 times) and grouped in the first and last paragraphs of the text. In the first lines we read I am speaking to you, it will be you, I want to speak with you today. Notice in this example, how the speaker does not use the expression "speak to you" but "speak with you" even though the characteristics of the venue do not permit this interaction. In the final part of the speech is where a big number of examples of the pronoun "you" can be found as subject. Let's take the examples you have the power, you can serve, you can conquer, you can do that, yes, you can and a final long sentence: the decisions that you make, the things that you do, and the hope that you hold. In this final assertion, he combines the use of the pronoun to address the audience directly, with the use of both repetition and parallelism.

Modality (grammar in Table 2) is expressed in this speech through the use of modal verbs in this order of frequency: will, can, must and fewer times, would and should, being the sum of will and can three times more often than must. The first one, with its future meaning, denotes the importance that Obama gives to the future of the nation. Expressions like we will pursue, we will fight, we will invest or will talk are examples of conciliatory tone. The modal can is used to reinforce the hopeful message. So, in the last part of the speech, he exhorts the audience to have courage for the future: You can conquer disease, end conflicts and make change from the bottom up. You can do that. Yes you can.

The percentage of use of the modal must with exhortative meaning, in contrast with the other ones, reflects the compromise he wants to establish with the country to fulfill the aims. It is an important part, but not the most frequent. We can see expressions like must start, must first recognize, must open, must include or must be won.

Other results are interesting. For instance, the active voice is used five times more often than the passive voice and the third person singular of the verb "to be" outnumber modal verbs in the present tense. Regarding the active voice, the use of the simple present, much more often than the present perfect, present continuous and simple past taken altogether is significant. Finally, there are two examples of imperative, that are used twice every one: let me be clear and make no mistake.

When passive voice is used, the aim is to denote criticism towards the government and citizens and to express the compromise that the visited country must sign in order to work together. So, we can find expressions like has yet to be fulfilled, is too often overlooked, can only be met by Africans, must also be broken, is the most threatened, can only be done.

The third group in our analysis model is cohesion and coherence. This is not seen so often in the repetition of simple and complex repetition, as we have seen, but in the examples of substitution of the pronouns and the number of generalizations. He names four big areas in his speech and explains with examples what he means by them. When he means "corruption", for instance, he exemplifies with tribalism and patronage. When talking about "opportunities", he names inversion, promotion, development and creation. Characteristics of "common humanity" are love to our communities, our faith and our family and when he talks about "power", he clarifies that is energy, solar power, wind, geothermal energy and bio-fuels. In other words, big topics are exemplified in Africa. To sum up, the speech is political in the sense that it deals with real economic problems that face Ghana and Africa but with a colloquial mood as they are explained with everyday examples. When he talks about natural gifts, Obama names several places in Africa where those resources can be found. As we see, the common rule followed by Obama is to switch from the general to the particular.

The contrast, on the other hand, is expressed in the problems or vices that really exist in Africa and in how people should change. We find words in the positive side that contradict the words in the negative side of the exposition. So, we can read in the same text terms like liberation and patronage; democracy and autocracy, tyranny; progress and poverty; corruption and transparency; peace and war, conflict; strength and brutality.

Taking into consideration Collins' (2010: p. 203) characteristics of the political discourse in written and spoken texts, we shall conclude that the paper we deal with has the following features in every category:

There are two other characteristics, that are, "Semi-natural vs. semi-learnt" and "Clause/phrase complexity" that are not included as can be considered belonging to both groups. In Table 6 we can see that written features are remarkable.

Focusing on the fourth group in Table 2, intertextuality is denoted in the knowledge President Obama has of the country and of the continent. In every one of the problems he faces, he exemplifies with different African countries. The bad aspects are reserved to other countries from Ghana. Another example of intertextuality is the reference he makes to Martin Luther King when he was in Ghana some decades ago. This is a recurrent tool for the "accreditation" of the text. "A speaker thus intimates his wish to pay honor to the previous text, so that the audience can follow the speaker in this respect too and can accept the orator's actual text by comparing it with the accredited pre-text”. (Sauer, in Schäffner: p. 39) He does it after naming the great effort African-Americans have done in his country, too.

Table 6.

Collins' characteristics of political discourse applied to the text.

\begin{tabular}{ll}
\hline \multicolumn{1}{c}{ SPOKEN } & \multicolumn{1}{c}{ WRITTEN } \\
\hline $\begin{array}{l}\text { Both individuals and languages } \\
\text { develop speech before writing }\end{array}$ & Specific equipment necessary \\
Coordination & Lexical features: precise reference \\
Organized in time & $\begin{array}{l}\text { Transmitted over considerable space and } \\
\text { time }\end{array}$ \\
Transient (although recorded) & Monologic \\
Context-bound & Static, closed \\
Presence of intonation and & Delayed feedback \\
body-language & Best suited for development of complex \\
Less audience-involving & ideas, allows planning, revision \\
& Prestigious, highly valued \\
& Syntactic features-clear sentence \\
& boundaries \\
& Complete major sentences \\
& Open-class words \\
& Lexically dense \\
& More formal, precise lexis \\
& Nominalizations \\
\hline
\end{tabular}


The association between two elements is also noticeable. The comparison between powerful nations and Ghana: The 21st century will be shaped by what happens not just in Rome or Moscow or Washington, but by what happens in Accra as well in order to reinforce the idea that their progress is in parallel with the world's in an attempt to make them feel part of the developed world.

The field is clearly defined but the mode is something that is worth a particular consideration. Typically, speech is associated with the presence of an addressee and, according to Collins (2010: p. 97), also with the following corollaries. We'll see which ones fit our text:

As we can see in Table 7, the characteristic factors in the speech mode do not fit completely. Collins provides a solution talking about the "mixed modes" (2010: p. 200):

Lectures are a good example of a mixed mode; they must provide precise information, but will not do so effectively without a degree of interpersonal contact: eye contact, spontaneous comment... the grammar of lectures will often reflect features of more informal tenor and of spoken mode, as for instance in its selection of coordination over subordination.

\section{Discussion}

Obama has wanted to show a deep knowledge of Ghana and of Africa. He names problems and achievements from different areas of different countries, individual people and, quite originnal, his own family. He attempts to make a parallelism between the positive evolution of three generations in his family and Ghana's.

In the vocabulary, some aspects must be taken into consideration. I have divided the words into five categories, according to their frequency: positive, negative, related to politics, neutral and with reference to countries. This distinction has been done not taking the words in isolation but within a context. So, for instance, civil society is neutral in itself but emerging civil society in the context used by Obama is positive. So the division into these categories has been done according to the intention of the author. In other examples we have checked that he uses an expression to be categorized as negative but has been used to contrast with a hopeful meaning. For instance, in the sentence Africa gives off less greenhouse gas than any other part of the world, but it is the most threatened by climate change, the expressions greenhouse gas and climate change are negative, although in the first case this is not related to Africa. Anyhow, we consider them negative for the implication it owns. On the contrary, the expression fight against HIV/AIDS has an intrinsic positive meaning but the word fight is traditionally considered negative. Not in this case, as has been used purposely with the meaning of a task developed with all the strength.

Obama has shown a deep knowledge of Africa, his countries and his problems and is also firm with corrupted administrations. Balance is put into Ghana, kind side of the coin, while other countries are openly criticized. As we saw in previous chapter, positive words double negatives because within positive words we find the praising to Ghana and the expectations that countries like this can have in future. Remember that half of the discourse deals with the four topics that represent the global problems in Africa.

The vocabulary words are not repeated, except in the few cases that we have named above. The use of shifters in the text
Table 7.

Corollaries in a speech act applied to the text.

\begin{tabular}{lc}
\hline Immediate feedback & NO \\
\hline Backchannelling & $?$ \\
Lack of preparation time & NO \\
Strategies of speaker/ addressee in- & YES (It is not a dialogue but the \\
teraction & public interacts) \\
Informality & NO \\
Rhetorical structure (extraposition) & YES \\
Functions of speech vs. writing & \\
Phatic function & NO \\
Interjections & NO \\
Poetic resources & YES \\
\hline
\end{tabular}

is also interesting. Patron and patronage are shifters used to describe some of the reasons why Africa has not evolved in a natural way. They do not describe a specific nation, except when talking about his grandfather that used the non-shifter British. On the other hand, there are not so many examples of equivalence. Just to cite one, we find Africa and developing world or the West. Added to this, when facing the problems of Africa, he also offers the solution with nouns like tragedies and triumphs, hope against cynicism and despair, patron versus partner, victors and opposition, support and violate or costs and resources.

But some examples have been found within the activity-related group of cohesive words. Most of the professions are quite general (farmers, producers, journalists) but they personify every measure: In the $21^{\text {st }}$ century, capable, reliable and transparent institutions are the key to success-strong parliaments and honest police forces; independent judges and journalists; a vibrant private sector and civil society.

It is remarkable the use of the indexical shifter "we" denoting "you and I" at the beginning and end of the text creates an atmosphere of confidence between the audience and the speaker. In a way, the orator feels closeness to the country and his problems. Also remarkable are the examples of parallelism. Firstly, the idea that their future is in their hands: As I said early, Africa's future is up to Africans. Secondly, using the negation: No country is going to create... No business wants to invest... No person wants to live... Thirdly, he reverses the problem of corruption empathasizing with Ghana and repeating the structure "we see": We see that in leaders who accept... We see that spirit in courageous... We see it in police... We see it in the young people... And the next paragraph in simple past: We saw it in Kenya... we saw it in South Africa... We saw it in Zimbabwe. Next, the repetition of the pronoun "we" is used to create the atmosphere of unity. Lastly, final lines are also examples of parallelism when he says: it must come from the decisions that you make, the things that you do, and the hope that you hold in your heart.

Intertextuality and its relatives are closely related to other pragmatic constructs, in particular, frames and presuppositions. So, the reference that Obama makes to his grandfather (first generation) and his father (second generation) leads Ghanaians to think of their own progress. The third generation (Obama) is the President of the United States of America. This message is encouraging and stimulating: personal effort has visible results.

Secondly, the reference to local and individual people who fought for their country's freedom, maybe unknown to the rest 
of the world, being the speaker's intention twofold: show a good knowledge of the recent story of the country and address specifically to them. This message is also of closeness and sympathy.

Thirdly, the reference to Martin Luther King. He is a wellknown character that represents justice and freedom for everybody, particularly for black people. He is an icon around the world. Obama makes reference to King's visit to Ghana some years before when the first step ahead in progress and freedom was accomplished. In this way, Obama is seen as the second revealing black person who goes to Ghana to give support to their efforts. This message is hopeful.

Parallelism and repetition as elements of text structure are used in several occasions throughout this speech in order to reinforce positive messages. But there is a sentence which he repeats twice purposely: Africa's future is up to African's. He repeats that at the beginning and close to the ending of the speech. The idea of the mutual responsibility is also constant. But there are other structures used to create a poetical feeling, for instance: “Your prosperity can expand America's. Your health and security... And the strength of your democracy can help..." All the achievements are reinforced through repetition, as is the case of "We see that in leaders... we see that spirit... we see it in police... we see it in the young people... and later "We saw it in Kenya... we saw it in South Africa... we saw it in Zimbabwe..." Corruption is condemned through negation: "No country is going to create... No business wants to invest... No person wants to live..." Another interesting example is the repetition of "you can" reminding the famous slogan in his successful presidential campaign: "You can serve in your communities... You can conquer disease... You can do that. Yes, you can.”

Taking the text as a whole, the structure is quite simple: the relationship between the nucleus and its ancillary satellites is coordinated. In all the topics he deals with, there is a correspondence between America or himself and Africa or Ghana. This correspondence requires some compromise. The message is that whether there is a response, we shall collaborate. We could see this in Table 8.

As we can see in Table 8, the compromise is established not just with Ghana, but with the rest of the countries, too. In fact, the funds for the public health support are not offered to Ghana, but Africa. Ghana is present during the whole speech but there is an addressee farther than this, Africa.

Following carrot and stick's theory and focusing on Ghana but extended to the rest of the countries, Obama gives three messages: I open my hands to help you, I expect from you a compromise, and provided that the compromise is fulfilled, these boundaries will be reinforced.

\section{Conclusion}

After a comprehensive analysis of the text we recognize that Obama has created a thin network between the messages he wants to transmit with a very conciliatory atmosphere. The affective bundle of boundaries, links, common knowledge of the country and understanding is more straightforward than the stylistic devices he exploits.

This interconnection is reflected, firstly, in the ties so much repeated in the first paragraphs and translated into compromise in next. No doubt, his roots are used not so much as a tool to show his understanding and knowledge of the country but as a
Table 8.

Structure of the speech.

\begin{tabular}{|c|c|c|}
\hline OBAMA/USA & & GHANA/AFRICA \\
\hline Obama's past & Current problems & Africa’s past/present \\
\hline $\begin{array}{l}\text { West's } \\
\text { responsibility }\end{array}$ & Democratic governments & Africa's responsibility \\
\hline $\begin{array}{l}\text { Help support } \\
\text { (\$3.5b.) }\end{array}$ & Opportunity = prosperity & Ghana \\
\hline Support (\$63b.) & Public health & $\begin{array}{l}\text { Africa' resources (and } \\
\text { Ghana's) }\end{array}$ \\
\hline \multirow[t]{2}{*}{ Promise of support } & Conflicts & $\begin{array}{l}\text { Africa's efforts (and } \\
\text { Ghana's) }\end{array}$ \\
\hline & & Ghana's honesty \\
\hline
\end{tabular}

means to show up his determination to fulfill the settled compromises.

Secondly, the high frequency of references to Africa opens up the message to the continent. The use of informal language and simple structures creates a colloquial environment where the first person pronoun singular is remarkable. The use of the simple present also reflects the degree of improvisation in the text. The orator feels self-confident enough to speak to an audience whose past and present he knows well. It is this knowledge that allows him to have these literary conventions throughout the text.

On the other hand, criticisms are always in opposition to praises. The switching towards the drawbacks always comes back to the appreciation of the achievements. Vocabulary is strong in these interventions and the use of adjectives is permanent in order to increase the tension. Criticisms are expressed as the necessary conditions to get this mutual help and can be summarized in the corruption of the institutions.

The important use of the modal "will" also reflects the importance given to the future and here is where this net is wider, as he involves all the continents in the globe with the personal pronoun "we" and with the use of hopeful metaphors.

The wide knowledge he shows of the continent is a signal of fellowship where problems are always expressed with solutions. The tone of the message is confident and constructive. Structures are simple to favor improvisation and further understanding. On the other hand, his interlinks of proper nouns and relevant people in the history of Africa diminish the original political bias that the text was designed for. At the same time, it creates intimacy with the audience.

To end with, he focuses the speech more on the future than the past and shows a determination to collaborate and work for Africa, albeit with very strict rules to be accomplished by honest governments.

\section{REFERENCES}

Bell, D. (1975). Power, influence and authority. New York, London, Toronto: Oxford University Press.

Brown, G., \& Yule, G. (1983). Discourse analysis. Cambridge: Cambridge University Press.

Cameron, L., \& Low, G. (1999). Researching and applying me-taphor. Cambridge, New York: Cambridge University Press.

Collins, P. (2010). English grammar: An introduction. Basingtoke, Hampshire, New York: Palgrave Macmillan.

Coulthard, M. (1994). Advances in written text analysis. London: Routledge. doi:10.4324/9780203422656

De Beaugrande, R., \& Dressler, W. (1981). Introduction to text linguis- 


\section{HERNÁNDEZ-GUERRA}

tics. London \& New York: Longman.

Ellis, D. G. (1992). From Language to communication (Communication Textbook Series: Language and Discourse Processes). Hillsdale, NJ: Erlbaum.

Enkvist, N. E. (1978). Coherence, Pseudo-coherence, and non-coherence. In J.-O. Östman (Ed.), Cohesion and Semantics (pp. 109-128). Âbo: Meddelanden frân Stiftelsens för Âbo Akademi forskningsinstitut.

Fairclough, (1992). Discourse and social change. Cambridge: Polity.

Goffman, E. (1981). Forms of talk. Oxford: Basil Blackwell.

Goos, L. (1995). By word of mouth: metaphor, metonymy, and linguistic action in a cognitive perspective. Amsterdam, PA: John Benjamins Publishing.

Halliday, M. A. K., \& Hasan, R. (1976). Cohesion in English. London: Longman.

Halliday, M. A. K., \& Hasan, R. (1985). An introduction to functional grammar. London: Edward Arnold.

Hellman, C. (1995). The notion of coherence in discourse. In G. Rickheit, \& Habel, C. (Eds.), Focus and coherence in discourse Processing (pp. 190-202). Berlin \& New York: de Gruyter.

Heydrich, W. (1989). Connexity and coherence: Analysis of text and discourse. Berlin, New York: Walter de Gruyter.

Jakobson, R. (1971). Fundamentals of language. The Hague: Mouton.

Kehler, A. (2002). Coherence, reference and the theory of grammar Stanford: CSLI Publications.

Korzen, I., \& Heslund, M. (1998). Clause combining and text structure. Frederiksberb: Samfundslitteratur.

Lakoff, R. T. (1990). The politics of language in our lives. New York: Basic Books.

Lakoff, R. T. (2000). The language war. Berkeley: University of California Press.

Lakoff, G., \& Johnson, M. (1980). Metaphors we live by. Chicago: Chicago University Press.

Leezenberg, M. (2001). Contexts of metaphor. Amsterdam, New York: Elsevier.

Levinson, S. C. (1988). Putting linguistics on a proper footing: Explorations in Goffman's concepts of participation. In P. Drew, \& A.
Wootton (Eds.), Erving goffman. Exploring the interaction order (pp. 161- 227). Cambridge: Polity Press.

Locke, T. (2004). Critical discourse analysis. London, New York: Continuum.

Lundquist, L. (1985). Coherence: From structures to processes. In E. Sözer (Ed.), Text, connexity, text coherence: Aspects, methods, results (pp. 151-175). Hamburg: Helmut Buske.

Martin, J. R. (1992). English text: System and structure. Amsterdam \& Philadelphia: John Benjamins.

Parrill, F., Tobin, V., \&Turner, M. (Eds.) (2010). Meaning, Form and body. Stanford, Calif: CSLI Publications

Rickheit, G., \& Habel, C. (1995). Focus on coherence in discourse processing. Berlin, New York: Walter de Gruyter.

Ritchie, D. (2006). Context and connection in metaphor. Basingstoke, New York: Palgrave Macmillan. doi:10.1057/9780230286825

Sanford, A. J., \& Moxey, L. M. (1995). Aspects of coherence in written language: A psychological perspective. In M. A. Gernsbacher, \& T. Givón (Eds.), Coherence in spontaneous text (pp. 161-187). Amsterdam \& Philadelphia: John Benjamins.

Schäffner, Ch. (1997). Analysing political speeches. Clevedon: Multilingual Matters LTD.

Simon-Vand, A. (2003). Grammatical metaphor: Views from systemic functional linguistics. Amsterdam, PA: Benjamins Publishing Co.

Simpson, P. (2010). Language and power. Cornwall: Routledge.

Tanskanen, S. (2006). Collaborating towards coherence: Lexical Cohesion in english discourse. Amsterdam, PA: John Benjamins Publishing Co.

Van Remortel, M. (1986). Literalness and metaphorization: The case of "turn". Wilrijk: Universiteit Antwerpen.

Vega Moreno, R. (2007). Creativity and convention: the pragmatics of everyday figurative language. Amsterdam, PA: John Benjamins Publishing

Wortham, S. E. F. (1996). Mapping participant deictics: A technique for discovering speaker's footing. Journal of Pragmatics, 25, 331-348. doi:10.1016/0378-2166(94)00100-6 